\title{
Aufgezeichnete Interviews
}

Dr. Wolfgang Beck: 8. März 2012.

Hans-Ulrich Büchting ( $\dagger$ ): 9. August 2009.

Ilse Denningmann: 7. März 2011.

Dr. Detlef Felken: 7. Februar 2013.

Jürgen Fischer: 26. Juli 2011.

Eva von Freeden: 26. Juli 2011.

Reinhard Gatz: 12. Juli 2010.

Prof. Dr. Martin Hielscher: 7. März 2012.

Dr. Ernst-Peter Wieckenberg: 6. März 2010, 28. Juli 2011 und 9. März 2012. 